\title{
Pengaruh Penambahan Isi Rumen dalam Ransum terhadap Konsumsi Nutrien pada Domba Pasca Sapih Dini
}

\author{
Effect of Rumen Content Addition in Diets on Nutrients Intake of Early-Weaned Lambs
}

\author{
Nuri Yasmina Amalia, Surono, dan Sutrisno
}

\author{
Departemen Peternakan, Fakultas Peternakan dan Pertanian, Universitas Diponegoro \\ Komplek drh. R. Soejono Koesoemowardojo, Tembalang, Semarang \\ Corresponding e-mail: yasminanuri20@gmail.com
}

\begin{abstract}
This research was aimed to study the effect of rumen contents addition in diets on organic matter (OM), extract ether (EE) and total digestible nutrients (TDN) intake of early-weaned lambs. Material used in this study were 15 heads of lamb, 2 - 3 weeks old with average body weight $4.37 \pm 1.11 \mathrm{~kg}$. The experimental design was completely randomized design (CRD) with5 treatments and 3 replications. The treatments used were $\mathrm{T} 0=$ starter feed without rumen contents addition + fodder $100 \mathrm{~g}, \mathrm{~T} 1=$ starter feed $+5 \%$ cattle rumen contents + fodder $100 \mathrm{~g}, \mathrm{~T} 2$ $=$ starter feed $+5 \%$ buffalo rumen contents + fodder $100 \mathrm{~g}, \mathrm{~T} 3=$ starter feed $+5 \%$ goat rumen contents + fodder 100 gand T4 $=$ starter feed $+5 \%$ sheep rumen contents+ fodder $100 \mathrm{~g}$. Parameters observed were OM, EE and TDN intake. Data were analyzed using analysis of variance in CRD. The result showed that rumen content addition from various kind of ruminants didn't give significant effect on OM, EE and TDN intake (P>0.05). The conclusion of this research was addition of rumen contents from different ruminant animals on early-weaned lambs diets did not increase OM, EE and TDN intake.
\end{abstract}

Key words: Rumen contents, nutrients intake, ruminants

\begin{abstract}
ABSTRAK
Penelitian ini bertujuan untuk mengkaji pengaruh penambahan isi rumen dalam ransum terhadap konsumsi bahan organik (BO), lemak kasar (LK) dan total digestible nutrients (TDN) domba pasca sapih dini. Materi yang

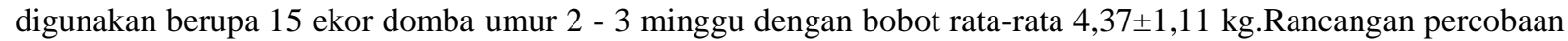
yang digunakan adalah rancangan acak lengkap (RAL) dengan 5 perlakuan dan 3 ulangan. Perlakuan yang diberikan yaitu $\mathrm{T} 0=$ pakan starter tanpa penambahan isi rumen + hijauan $100 \mathrm{~g}$, T1 = pakan starter $+5 \%$ isi rumen sapi+ hijauan $100 \mathrm{~g}$, T2 = pakan starter $+5 \%$ isi rumen kerbau+ hijauan $100 \mathrm{~g}, \mathrm{~T} 3=$ pakan starter $+5 \%$ isi rumen kambing+ hijauan $100 \mathrm{~g}$ dan $\mathrm{T} 4=$ pakan starter $+5 \%$ isi rumen domba+ hijauan $100 \mathrm{~g}$. Parameter yang diamati yaitu konsumsi BO, LK dan TDN. Hasil penelitian menunjukkan bahwa penambahan isi rumen berbagai ternak ruminansia tidak berpengaruh nyata $(\mathrm{P}>0,05)$ terhadap konsumsi BO, LK dan TDN. Simpulan dari penelitian ini yaitu penambahan isi rumen berbagai ternak ruminansia dalam ransum ternak domba pasca sapih dini tidak meningkatkan konsumsi BO, LK dan TDN.
\end{abstract}

Kata kunci: Isi rumen, konsumsi nutrien, ruminansia

\section{PENDAHULUAN}

Peningkatan kebutuhan daging masyarakat Indonesia harus diimbangi dengan peningkatan produksi dan produktivitas ternak.Ternak ruminansia merupakan salah satu ternak yang berperan dalam menghasilkan daging dimana ternak ruminansia memerlukan bantuan mikroba dalam mencerna pakannya.Ternak ruminansia muda belum sempurna dalam memfermentasikan pakan di dalam rumen karena saluran pencernaannya masih mengalami perkembangan. Perkembangan saluran pencernaan ruminansia dapat dirangsang dengan memberi pakan starter dan probiotik sebagai pakan tambahan (Pamungkas dan Anggraeny, 2006).

Probiotik merupakan produk yang berasal dari kultur mikroba yang ditambahkan dalam pakan dalam jumlah yang tertentu. Salah satu bahan yang yang dapat dimanfaatkan sebagai probiotik yaitu isi rumen ternak karena isi rumen merupakan pakan yang belum terfermentasi sempurna di dalam rumen dan masih mengandung sel-sel mikroba, asam amino, protein kasar, saliva, asam lemak atsiri dan vitamin (Oladefahan, 2014; Al-Wazeer, 2016). Jenis bakteri yang 
banyak ditemukan dalam isi rumen adalah bakteri selulolitik serat misalnya Fibrobacter succinogenes, Ruminococcus flavefaciens dan Ruminococcus albus (Cherdthong et al., 2015). Mikroba yang terkandung dalam isi rumen bersifat dapat hidup di dalam saluran pencernaan ternak dan dapat memberikan efek positif bagi induk semang (Pamungkas dan Anggraeny, 2006).

Isi rumen dari masing-masing jenis ternak ruminansia mengandung jumlah populasi mikroba yang berbeda-beda. Rumen sapi mengandung bakteri sebanyak $2,1 \times 10^{10}$ $\mathrm{ml}^{-1}$ (Purbowati et al., 2014). Populasi bakteri rumen kerbau mencapai $10^{11} \mathrm{~g}^{-1}$ (Franzolin dan Wright, 2016), kambing 10,5 x $10^{10} \mathrm{ml}^{-1}$ (Liu et al., 2017) dan domba 1,6 x $10^{10} \mathrm{~g}^{-1}$ (Wora-anu et al., 2007). Selain banyaknya populasi mikroba, perbedaan isi rumen dari berbagai ternak ruminansia yaitu berupa jenis spesies mikroba. Cairan rumen kambing banyak mengandung populasi Selenomonas ruminantium karena kambing lebih cenderung untuk mengkonsumsi dedaunan dari tanaman spesies Acacia spp. (Skene dan Brooker, 1995). Bakteri Selenomonas berperan dalam menfermentasi gula dan dapat tumbuh dengan mudah jika berada dalam kondisi lingkungan yang mengandung konsentrasi tanin dalam jumlah yang tinggi (Odenyo dan Osuji, 1998). Populasi protozoa dalam cairan isi rumen kerbau lebih tinggi dari sapi. Protozoa spesies Epidinium ecuadatum dan Diplodinium crystagali dapat ditemukan pada cairan rumen kerbau namun tidak ditemukan pada sapi (Jabari et al., 2014). Epidinium ecaudatum lebih mampu untuk mendegradasi mikrokristal selulosa dibandingkan Entodinium maggi pada cairan rumen kerbau dan sapi (Coleman, 1985).

Penambahan isi rumen ke dalam ransum dapat mempengaruhi sifat fisik, kimiawi dan kandungan nutrien dan palatabilitas ransum (Zain, 2009). Kandungan nutrien dan palatabilitas pakan dapat mempengaruhi kecernaan di dalam rumen sehingga menentukan nilai konsumsi ternak (Paramita et al., 2008). Banyaknya nutrien yang terkonsumsi berpengaruh terhadap energi yang dihasilkan oleh tubuh untuk memenuhi kebutuhan hidup pokok (maintenance), pertumbuhan dan produksi ternak (Astuti et al., 2009). Hal ini menunjukkan bahwa perlu pembahasan lebih lanjut mengenai pengaruh penambahan isi rumen dalam ransum terhadap konsumsi bahan organik (BO), lemak kasar (LK) dan total digestible nutrients (TDN). Penelitian ini bertujuan untuk mengkaji pengaruh penambahan isi rumen berbagai ternak ruminansia dalam ransum terhadap konsumsi BO, LK dan TDN domba pasca sapih dini.

\section{MATERI DAN METODE}

Penelitian ini dilaksanakan pada bulan Agustus 2017 - Januari 2018 di kandang Digesti Fakultas Peternakan dan Pertanian Universitas Diponegoro, Semarang. Analisis proksimat sampel dilakukan di Laboratorium Ilmu Nutrisi dan Pakan Fakultas Peternakan dan Pertanian Universitas Diponegoro, Semarang. Materi yang digunakan pada penelitian ini berupa 15 ekor domba ekor tipis (DET) dengan umur 2 - 3 minggu dengan bobot rata-rata 4,37 $\pm 1,11$ $\mathrm{kg}$. Bahan yang digunakan antara lain ransum danisi rumen dari berbagai ternak. Ransum tersusun dari pollard, dedak, bungkil kelapa, bungkil kedelai, molases dan mineral. Isi rumen yang digunakan berupa isi rumen sapi, kerbau, kambing dan domba. Formulasi pakan starter tertera pada Tabel 1 .

Penelitian ini menggunakan rancangan percobaan berupa rancangan acak lengkap (RAL) dengan 5 perlakuan dan 3 ulangan. Perlakuan yang digunakan yaitu:

T0 = pakan starter tanpa penambahan isi rumen + hijauan $100 \mathrm{~g}$

$\mathrm{T} 1=$ pakan starter + isi rumen sapi sebanyak $5 \%$ + hijauan $100 \mathrm{~g}$

$\mathrm{T} 2=$ pakan starter + isi rumen kerbau sebanyak 5\% + hijauan $100 \mathrm{~g}$

$\mathrm{T} 3=$ pakan starter + isi rumen kambing sebanyak 5\% + hijauan $100 \mathrm{~g}$

T4 = pakan starter + isi rumen domba sebanyak 5\% + hijauan $100 \mathrm{~g}$ 
Tabel 1. Kandungan nutrien pakan starter

\begin{tabular}{lccccc}
\hline \multirow{2}{*}{ Nutrisi bahan pakan } & \multicolumn{5}{c}{$\begin{array}{l}\text { Perlakuan } \\
(\%)\end{array}$} \\
\cline { 2 - 6 } & T0 & T1 & T2 & T3 & T4 \\
\hline BK & 88,51 & 88,46 & 88,38 & 88,39 & 88,30 \\
Abu & 7,52 & 7,98 & 7,98 & 7,78 & 7,89 \\
LK & 4,73 & 4,86 & 4,70 & 4,71 & 4,67 \\
SK & 15,39 & 16,97 & 16,67 & 17,02 & 16,80 \\
PK & 17,02 & 16,91 & 16,68 & 16,90 & 16,90 \\
BETN $^{1}$ & 55,34 & 53,28 & 53,97 & 53,58 & 53,75 \\
TDN $^{2}$ & 71,22 & 69,18 & 69,28 & 69,14 & 69,27 \\
\hline
\end{tabular}

Keterangan: 1. Dihitung menggunakan rumus Hartadi et al. (2005), 2. Dihitung menggunakan rumus Sutardi (2001)

Data hasil penelitian diolah menggunakan analisis ragam dan jika hasil menunjukkan pengaruh nyata $(\mathrm{P}<0,05)$ maka dilanjutkan dengan uji Duncan.

Penelitian dilakukan dalam tiga tahap yaitu tahap persiapan, tahap pelaksanaan dan tahap pengumpulan data. Tahap persiapan yaitu penyiapan bahan pakan dan isi rumen berbagai ternak ruminansia. Selanjutnya bahan pakan disusun dan dicampur menjadi ransum menyesuaikan kebutuhan ternak.Tahap pemeliharaan yaitu ternak dipelihara selama 10 minggu dan diberi ransum perlakuan. Pengambilan data yang dilakukan meliputi penimbangan dan pengambilan sampel pakan pemberian dan pakan sisa.Pakan yang telah di sampling kemudian dianalisis. Parameter yang diamati dalam penelitian ini adalah:

1. Konsumsi BO (g/ekor/hari) adalah banyaknya konsumsi BK pakan dikalikan dengan kadar BO pakan.

2. Konsumsi LK (g/ekor/hari) adalah banyaknya konsumsi BK pakan dikalikan dengan kadar LK pakan.

3. Konsumsi TDN (g/ekor/hari) adalah banyaknya konsumsi BK pakan dikalikan dengan TDN pakan.
Kandungan TDN pakan dihitung menggunakan rumus Sutardi (2001).

\section{HASIL DAN PEMBAHASAN}

Rata-rata konsumsi bahan kering (BK), bahan organik (BO), lemak kasar (LK) dan total digestible nutrients (TDN) masingmasing perlakuan terdapat pada Tabel 2 .

\section{Konsumsi Bahan Organik}

Hasil penelitian konsumsi BO akibat penambahan isi rumen dalam ransum dilihat pada Tabel 2.Analisis ragam menunjukkan bahwa perlakuan penambahan isi rumen dalam ransum tidak berpengaruh nyata. Ratarata konsumsi BO perlakuan T0, T1, T2, T3 dan T4 masing-masing yaitu 240,50; 196,53; 248,08; 251,75; dan 205,81 g/ekor/hari atau setara dengan 52,$51 ; 49,38 ; 56,25 ; 61,70$ dan $42,97 \mathrm{~g} / \mathrm{kg}$ BB/hari. Nilai tersebut lebih tinggi dibandingkan dengan penelitian Suparjo et al. (2011) yang menyatakan bahwa domba dengan bobot 11,6 $\pm 1,5 \mathrm{~kg}$ memiliki konsumsi BO sekitar 368 - 492 g/ekor/hari atau setara dengan 31,72 - 42,41 $\mathrm{g} / \mathrm{kg} \mathrm{BB} / \mathrm{hari}$.

Tabel 2. Rata-rata konsumsi nutrien

\begin{tabular}{lccccc}
\hline Parameter & T0 & T1 & T2 & T3 & T4 \\
\hline & & $---------(g /$ ekor/hari $)$ & -------- & \\
Konsumsi BO & 240,50 & 196,53 & 248,08 & 251,75 & 205,81 \\
Konsumsi LK & 14,33 & 12,21 & 15,25 & 15,29 & 12,40 \\
Konsumsi TDN & 217,25 & 172,85 & 223,64 & 226,13 & 179,39 \\
\hline
\end{tabular}

Keterangan: nilai rata-rata konsumsi $\mathrm{BO}, \mathrm{LK}$ dan TDN menunjukkan tidak berbeda nyata $(\mathrm{P}>0,05)$ 
Konsumsi BO antarperlakuan bernilai relatif sama dikarenakan penambahan isi rumen berbagai ternak ruminansia dalam ransum tidak mempengaruhi kandungan BK dan BO dalam pakan. Bahan Organik pakan merupakan komponen dari BK pakan sehingga konsumsi BK pakan yang tidak berbeda menyebabkan konsumsi $\mathrm{BO}$ juga tidak berbeda. Aryanto et al. (2013) dan Suwignyo (2016) menyatakan bahwa kandungan BO suatu pakan adalah bagian dari BK pakan sehingga konsumsi BK pakan berpengaruh sangat besar pada konsumsi BO pakan. Munawaroh, et al (2015) menyatakan bahwa BO terdiri dari SK, PK, LK dan BETN sehingga konsumsi BO berkorelasi dengan konsumsi BK.

Pemanfaatan isi rumen dari berbagai ternak ruminansia sebagai probiotik tidak meningkatkan konsumsi BO. Hal ini sependapat dengan Mondal et al. (2013) bahwa pemanfaatan isi rumen ke dalam ransum pada taraf $10 \%$ tidak mempengaruhi konsumsi BK dan BO ternak. Hau et al. (2005) menyatakan bahwa pemberian isi rumen sebagai probiotik kepada ternak tidak dapat mempengaruhi konsumsi BO jika sifat pakan dan nutrien yang terkandung dalam ransum pemberian yang relatif sama. Nilai konsumsi BO yang relatif sama diduga karena perlakuan pengeringan terhadap isi rumen menyebabkan jumlah populasi mikroba relatif sama sehingga penambahan isi rumen berbagai ternak sebesar $5 \%$ bernilai relatif kecil untuk mempengaruhi proses fermentasi dan laju pencernaan di dalam rumen. Khalid et al. (2011) menyatakan bahwa penambahan probiotik dapat meningkatkan konsumsi apabila probiotik tersebut mempengaruhi $\mathrm{pH}$ rumen dan meningkatkan kecernaan nutrien di rumen.

\section{Konsumsi Lemak Kasar}

Hasil penelitian konsumsi LK akibat penambahan isi rumen dalam ransum dilihat pada Tabel 2. Analisis ragam menunjukkan bahwa perlakuan penambahan isi rumen dalam ransum tidak berpengaruh nyata. Ratarata konsumsi LK perlakuan T0, T1, T2, T3 dan T4 masing-masing yaitu 14,$33 ; 12,21$;
15,$25 ; 15,29$ dan 12,40 g/ekor/hari atau setara dengan 3,$12 ; 3,07 ; 3,46 ; 3,75$ dan 2,6 $\mathrm{g} / \mathrm{kg} \mathrm{BB} /$ hari. Nilai konsumsi tersebut lebih tinggi dari penelitian Sitohang et al. (2012) yang menyatakan bahwa domba dengan bobot18 - 18,2 kg memiliki konsumsi LK pakan sebesar 10,2 - 12,1 g/ekor/hari atau setara dengan $0,6-0,7 \mathrm{~g} / \mathrm{kg} \mathrm{BB} / \mathrm{hari}$.

Konsumsi LK tidak berbeda nyata dikarenakan penambahan isi rumen dari berbagai ternak ruminansia tidak mempengaruhi kandungan LK dalam ransum. Kandungan LK antarperlakuan yang bernilai relatif sama menyebabkan konsumsi LK ternak tidak berbeda. Menurut Nurhajah et al. (2016) konsumsi LK pakan dipengaruhi oleh kadar LK dalam pakan. Sitohang et al. (2012) menyatakan bahwa faktor yang mempengaruhi konsumsi LK antara lain perlakuan pakan, palatabilitas, kandungan asam lemak tak jenuh dan tingkat kecernaan pakan. Penambahan isi rumen dari berbagai ternak sebanyak $5 \%$ bernilai relatif kecil dan menyebabkan mikroba dalam isi rumen tidak mempengaruhi kecernaan lemak di dalam rumen sehingga konsumsi lemak juga bernilai relatif sama. Hau et al. (2005) penambahan probiotik isi rumen tidak dapat mempengaruhi konsumsi nutrien pakan namun dapat meningkatkan kecernaan apabila pemberian probiotik dapat memberikan pengaruh positif terhadap $\mathrm{pH}$ rumen dan interaksi antara mikroba dari probiotik isi rumen dengan mikroba ternak.

\section{Konsumsi Total Digestible Nutrients}

Hasil penelitian konsumsi TDN akibat penambahan isi rumen dalam ransum dilihat pada Tabel 2. Analisis ragam menunjukkan bahwa perlakuan penambahan isi rumen dalam ransum tidak berpengaruh nyata. Rata-rata konsumsi TDN dari masingmasing perlakuan T0, T1, T2, T3 dan T4 yaitu 217,$25 ; 172,85 ; 223,64 ; 226,13$ dan 179,39 g/ekor/hari. Konsumsi TDN ternak sudah mencukupi standar kebutuhan TDN domba dengan bobot 5-10 kg menurut Kearl (1982) yaitu 120 - 360 g/ekor/hari.

Penambahan isi rumen berbagai ternak ruminansia tidak berpengaruh 
terhadap konsumsi TDN. Hal ini sependapat dengan Mondal et al. (2013) menyatakan bahwa pemanfaatan isi rumen $10 \%$ ke dalam ransum tidak berpengaruh nyata pada konsumsi TDN. Konsumsi TDN antarperlakuan tidak berbeda nyata dikarenakan kandungan nutrien ransum, TDN ransum masing-masing perlakuan bernilai relatif sama. Nugroho et al. (2013) menyatakan bahwa konsumsi TDN ternak dapat bernilai sama karena kandungan nutrien dan energi ransum yang sama.

Nilai konsumsi BO dan LK pakan yang relatif samajuga dapat menyebabkan konsumsi TDN juga bernilai relatif sama.Hal ini dikarenakan nilai konsumsi TDN dipengaruhi oleh banyaknya nutrien yang terkonsumsi. Menurut Mastopan et al. (2014) faktor-faktor yang berperan dalam mempengaruhi konsumsi TDN ternak ruminansia antara lain kecernaan $\mathrm{BO}$ dan kandungan nutrien pakan meliputi SK, PK, LK dan BETN. Menurut Nurhajah et al. (2016) LK pakan dapat memproduksi energi 2,25 kali lebih besar dibandingkan energi dari karbohidrat baik serat kasar maupun BETN.

\section{KESIMPULAN}

Kesimpulan dari penelitian ini yaitu penambahan isi rumen dari berbagai ternak ruminansia dalam ransum ternak domba pasca sapih dini tidak meningkatkan konsumsi BO, LK dan TDN. Saran yang dapat diberikan yaitu perlu dilakukan penelitian lanjutan mengenai pengaruh penambahan isi rumen dalam ransum ternak ruminansia pada taraf pemberian yang berbeda.

\section{DAFTAR PUSTAKA}

Al-Wazeer, A.A.M. 2016. Effect of different levels of dried rumen content on nutrient intake, digestibility and growth performance of Awassi lambs. Int. J. Adv. Res. 4 (9): 2106 - 2113.

Aryanto, B. Suwigyo dan Panjono. 2013. Efek pengurangan dan pemenuhan kembali jumlah pakan terhadap konsumsi dan kecernaan bahan pakan pada kambing Kacang dan Peranakan Etawah. Buletin Peternakan. 37 (1): $12-18$.

Astuti, A., A. Agus dan S.P.S. Budhi. 2009. Pengaruh penggunaan high quality feed supplement terhadap konsumsi dan kecernaan nutrien sapi perah awal laktasi. Buletin Peternakan. 33 (2): 81-87.

Coleman, G.S. 1985. The cellulase content of 15 species of entodiniomorphid protozoa, mixed bacteria and plant debris isolated from the ovine rumen. J. Agric. Sci. Camb. 104: 349 - 360.

Cherdthong, A., M. Wanapat, A. Saenkamsorn. 2015. Improving rumen ecology and microbial population by dried rumen digesta in beef cattle. Trop. Anim. Health Prod. 47: 921 - 926.

Franzolin, R. dan A.D.G. Wright. 2016. Microorganisms in the rumen and reticulum of buffalo (Bubalus bubalis) fed two different feeding systems. J. BMC Research Notes. 9 (243): 1 - 5 .

Hartadi, H., S. Reksohadiprodjo dan A.D. Tillman. 2005. Tabel Komposisi Pakan untuk Indonesia. Gajah Mada University Press, Yogyakarta.

Hau, D. K., M. Nenobais, J. Nulik dan N.G.F. Katipana. 2005. Pengaruh probiotik terhadap kemampuan cerna mikroba rumen sapi bali. Seminar Nasional Teknologi Peternakan dan Veteriner. Inovasi Teknologi Peternakan untuk Meningkatkan Kesejahteraan Masyarakat dalam Mewujudkan Kemandirian dan Ketahanan Pangan Nasional. Pusat Penelitian dan Pengembangan Peternakan, Bogor, $171-180$. 
Jabari, S., M. Eslami, M. Chaji, T. Mohammadabadi, M. Bojarpour. 2014. Comparison digestibility and protozoa population of Khuzestan water buffalo and Holstein cow. Vet. Res. Forum. 5 (4): 295 - 300.

Kearl, L.C. 1982. Nutrient Requirements of Ruminants in Developing Countries. International Feedstuff Institute Utah Agriculture Exploration Utah State University, Utah.

Khalid, M.F., M.A. Shahzad, M. Sarwar, A.U., Rehman, M. Sharif dan N. Mukhtar. 2011. Probiotics and lamb performance: A review. African J. Agric. Res. 6 (23): 5198- 5203.

Liu, K., Q. Xu, L. Wang, J. Wang, W. Guo dan M. Zhou. 2017. The impact of diet on the composition and relative abundance of rumen microbes in goat. Asian-Aust. J. Anim. Sci. 30 (4): 531 $-537$.

Mastopan, M. Tafsin dan N.D. Hanafi. 2014. Kecernaan lemak kasar dan TDN (total digestible nutrients) ransum yang mengandung pelepah daun kelapa sawit dengan perlakuan fisik, kimia, biologis dan kombinasinya pada domba. Jurnal Peternakan Integratif. 3 (1): 37 - 45 .

Mondal, S., S. Haldar, I. Samanta, G. Samanta dan T.K. Ghosh. 2013. Exploring nutritive potential of undigested rumen contents as an ingredient in feeding of goats. Anim. Nutr. Feed Tech. 13: 79 - 88.

Munawaroh, L.L., I.G.S. Budiasatria dan B. Suwignyo. 2015. Pengaruh pemberian fermentasi complete feed berbasis pakan local terhadap konsumsi, konversi pakan, dan feed cost kambing Bligon Jantan. Buletin Peternakan. 39 (3): 167 -173.

Nugroho, D., A. Purnomoadi dan E. Riyanto. 2013. Pengaruh imbangan protein kasar dan total digestible nutrient pada pakan yang berbeda terhadap pemanfaatan energi pakan pada domba lokal. Sains Peternakan, 11 (2): 63 - 69 .

Nurhajah, A., A. Purnomoadi dan D.W. Harjanti. 2016. Hubungan antara konsumsi serat kasar dan lemak kasar dengan kadar total solid dan lemak susu kambing Peranakan Ettawa. Agripet. 16 (1): 1 - 8.

Oladefahan, O.A. 2014. Evaluation of bovine rumen contents as a feed for lambs. Trop. Anim. Health Prod. 46 (6): 939 $-945$.

Odenyo, A. A., and Osuji, P. O. 1988. Tannin tolerant ruminal bacteria from East African ruminants. Canad. J. Microbiol. 44, 905 - 909.

Pamungkas, D. dan Y.N. Anggraeny. 2006. Probiotik dalam pakan ternak ruminansia. Wartazoa. 16 (2): 82 - 91.

Paramita, W., W.E. Susanto dan A.B. Yulianto. 2008. Konsumsi dan kecernaan bahan kering dan bahan organik dalam haylase pakan lengkap ternak sapi Peranakan Ongole. Media Kedokteran Hewan. 24 (1): 59 - 62.

Purbowati, E., E. Rianto, W.S. Dilaga, C. M. S. Lestari dan R. Adiwinarti. 2014. Karakteristik cairan rumen, jenis, dan jumlah mikrobia dalam rumen sapi Jawa dan Peranakan Ongole. Buletin Peternakan. 38 (1): 21 - 26.

Sitohang, A., D. Sudrajat dan E. Dihansih. 2012. Performa pertumbuhan domba lokal jantan yang mendapat pakan tepung kulit kopi. Jurnal Pertanian, 3 (2): $78-90$.

Skene, I. K. dan J. D. Brooker. 1995. Characterization of tannin acylhydrolase activity in the ruminal bacterium Selenomonas ruminantium. Anaerobe. 1: $321-327$. 
Suparjo, K.G. Wiryawan, E. B. Laconi dan D. Mangunwidjaja. 2011. Performa kambing yang diberi kulit buah kakao terfermentasi. Media Peternakan. 35 41.

Sutardi, T. 2001. Revitalisasi Peternakan Sapi Perah Melalui Penggunaan Ransum Berbasis Limbah Perkebunan dan Suplemen Mineral Organik. Laporan Akhir RUT VIII.1. Kantor Menteri Negara Riset dan Teknologi dan Lembaga Ilmu Pengetahuan Indonesia, Jakarta.

Suwignyo, B., U. A. Wijaya, R. Indriani, A. Kurniawati, I. Widiyono dan Sarmin. 2016. Konsumsi, kecernaan nutrien, perubahan berat berat badan dan status fisiologis kambing Bligon jantan dengan pembatasan pakan. Jurnal Sain dan Veteriner. 34 (2): 210 -219 .

Woraanu, S., M. Wanapat, C. Wachirapakorn dan N. Nontaso. 2007. Effect of roughage sources on cellulolytic bacteria and rumen ecology of beef cattle. Asian-Aust. J. Anim. Sci. 20 (11): $1705-1712$.

Zain, M. 2009. Substitusi rumput lapangan dengan kulit buah coklat amoniasi dalam ransum domba lokal. Media Peternakan. 32 (1): $47-52$. 